\title{
Effect of mixed use of thyme and fennel oils on biochemical properties and electrolytes in rainbow trout as a response to Yersinia ruckeri infection
}

\author{
Azime Kucukgul Gulec, Durali Danabas, Mesut Ural, Engin Seker, Ali Arslan, \\ Osman Serdar
}

Tunceli University, Fisheries Faculty, Tunceli, Turkey

Received November 27, 2012

Accepted June 19, 2013

\begin{abstract}
The aim of study was to compare the effects of supplementation of food with herbal oils (Thymus vulgaris and Foeniculum vulgare) on biochemical properties and electrolytes of rainbow trout infected with Yersinia ruckeri. In total, 120 healthy fish (mean weight $84 \pm 1.02 \mathrm{~g}$ ) were equally divided into four experimental groups. The experimental study was carried out for one week. The first group was control without supplementation and infection, the second group was infected and without oil supplementation, the third group was supplemented with oils (10 ml·100 $\mathrm{g}^{-1}$ rates) for one week and infected with Y. ruckeri and the last group was oil supplemented without infection. Results indicated that fish fed with dietary supplements showed enhanced bactericidal activity, total protein, albumin, cholesterol, triglyceride and bilirubin compared to the control $(P<0.05)$. As the value of herbal oils was increased in diets, the plasma glucose level decreased. The levels of $\mathrm{K}, \mathrm{Na}, \mathrm{Ca}$, and $\mathrm{Mg}$ increased whereas $\mathrm{Cl}$ values decreased, compared to the control. It can be concluded that diet supplementation with herb oils used in this study can increase disease resistance by increasing levels of some biochemical parameters and electrolytes in rainbow trout to $Y$. ruckeri infection.
\end{abstract}

Thymus vulgaris, Foeniculum vulgare, Oncorhynchus mykiss, biochemical indices

The massive use of antimicrobials for disease control has suppressed the growth of aquatic animals since it leads to antibiotic and chemical resistance and consumer unwillingness (Smith et al. 1994; MacMillan 2001). To reduce or avoid the dependence of aquaculture on antibiotics, some products of natural plant origin have been considered as an effective alternative way to control bacterial and viral infections (Harikrishnan et al. 2010; Kirubakaran et al. 2010). Several antimicrobial, anti-stress, immunostimulant and growth-promoting plant products significantly influence the health of fish (Dada and Ikuerowo 2009). Plant phenolics, polysaccharides, proteoglycans, and flavonoids play a major role in preventing or controlling infectious microbes (Citarasu 2010).

Natural products are an important source of new chemical compounds and, hopefully, therapeutic agents for many bacterial diseases. Thyme (Thymus vulgaris Linnaeus), belonging to the Lamiaceae family, is a pleasant-smelling perennial shrub, which grows in several regions in the world (Davis 1982). T. vulgaris is a well-known aromatic plant and its essential oil and aromatic water are used in the mountainous areas of the Mediterranean Region in Turkey (Baytop 1984; Akgul 1993). Fennel (Foeniculum vulgare Miller) is an aromatic herb used in traditional medicine and as spice in Central Europe and the Mediterranean. In previous studies, natural plant extracts including essential oils (thymol, flavonoids and phenolic compounds) have been found to have antibacterial activity (Essawi and Srour 2000). The antifungal and antibacterial activity exhibited by the Thymus genus essential oil has been demonstrated by several researchers (Karaman et al. 2001; Rasooli and Mirmostafa 2003). Fennel is known as an excellent source of natural antioxidants and contributes to daily antioxidant diet (Shahat et al. 2011). In addition, the usage of herbal mixtures significantly improved the immune indicators (albumin-globin

Address for correspondence:

Azime Kucukgul Gulec

Fisheries Faculty

Tunceli University

TR62000, Tunceli, Turkey
Phone: +90 (428)2131864

Fax: +90 (428) 2131861

E-mail: agulec@tunceli.edu.tr

http://actavet.vfu.cz/ 
ratio etc.) and performance of haematological and biochemical properties in fish and shrimp (Sivaram et al. 2004; Citarasu et al. 2006).

Electrolytes are also required for normal life processes in fish. Some of them, e.g., magnesium $(\mathrm{Mg})$, Zinc $(\mathrm{Zn})$ and iron $(\mathrm{Fe})$, are obtained from the diet or from water. Generally, electrolytes carry out several homeostatic functions, such as bone formation, polarization of membranes, integration of enzymatic systems, energy storage, acid-base balance, clotting and respiration (Coppo 2001). Moreover, mineral deficiencies may cause biochemical, structural and functional pathologies, which depend on several factors, especially on the duration and degree of mineral deprivation. Sugiura et al. (1998) suggested that the availability of minerals increased when diets became acidified, and decreased when minerals were added to diets.

The aim of this study was to evaluate the effects of mixed use of oils (T. vulgaris and F. vulgare) in diets on selected biochemical properties and electrolytes in plasma of rainbow trout (Oncorhynchus mykiss Walbaum, 1792) infected with Yersinia ruckeri.

\section{Materials and Methods}

Preparation of herbal oils

The herbal oils were obtained from a commercial company (Elazığ, Turkey) and their compositions were determined by gas chromatography-mass spectrometry (GC-MS) in laboratories of the TUBITAK Marmara Research Centre (Istanbul, Turkey). Gas chromatograph (GC) analyses were carried out on a Shimadzu GC-9A gas chromatograph equipped with Thermon-600 T (30 $\mathrm{m} \times 0.25 \mathrm{~mm} \times 0.25 \mu \mathrm{m}$ film thickness) (Bagamboula et al. 2004).

Screening herbal oils

Screening of herbal oils for their antibacterial activity against $Y$. ruckeri was conducted using the disc diffusion method as described by Bauer et al. (1996). All the tests were replicated three times. Inhibition zone of per herbal oil was measured and recorded. Minimal inhibitory concentration (MIC) was determined as the lowest concentration and the highest dilution, which completely inhibited the growth of Y. ruckeri by an agar plate dilution method according to CLSI (2003). Minimal inhibitory concentration values of herbal oils were solved in $1 \mathrm{ml}$ of the Mueller-Hinton broth medium. Similar to what was mentioned before, $3 \times 10^{7} \mathrm{cfu} \cdot \mathrm{ml}^{-1}$ bacteria were added to each test tube and after 24-hour of incubation at $35^{\circ} \mathrm{C}$, the MIC values for each of herbal oil were determined in $\mu \mathrm{g}^{\mathrm{m}} \mathrm{ml}^{-1}$.

The experimental diets were prepared by pulverization method. Diets were dried in open air, packed and stored to be used later in experiment.

\section{Bacterial challenge}

Yersinia ruckeri (ATCC 29473) was provided by the Pendik Veterinary Research Institute (Istanbul, Turkey) and stored at $-80{ }^{\circ} \mathrm{C}$. To determine the optimum bacterial cell concentration for the experiment, graded doses ranging from $10^{10}$ to $10^{4} \mathrm{of} \mathrm{cfu} \cdot \mathrm{ml}^{-1}$ were utilized. The median lethal dose $\left(\mathrm{LD}_{50}\right)$ calculated by the method of Reed-Muench (1938) was $3 \times 10^{7} \mathrm{cfu} \cdot \mathrm{ml}^{-1}$ and this concentration was used for the experiment.

Feeding and sampling

In total, 120 healthy fish (weight $84 \pm 1.02 \mathrm{~g}$ ) were divided into four experimental groups: Control - 30 fish without oil supplementation and infection, INF - fish infected with Y. ruckeri but without oil supplementation, OIL1 - fish with oil supplementation and infected with Y. ruckeri, OIL2 - fish with oil supplementation but without infection. Fish were stocked in tanks (450 1) with water re-circulated and aerated at $12 \mathrm{~h} \mathrm{light/12} \mathrm{h} \mathrm{dark}$ period for 1 week at $17 \pm 1{ }^{\circ} \mathrm{C}$. Each fish group was fed twice a day at 9:00 $\mathrm{h}$ and 17:00 $\mathrm{h}$ at the amount of 3\% live body weight. Fish in CNT and INF groups were fed a commercial fish feed while fish in groups of OIL1 and OIL2 were orally fed feeds with oil mixture at a dose of $10 \mathrm{ml} \cdot 100 \mathrm{~g}^{-1}$ for 1 week.

After acclimatization, each fish in group of INF and OIL1 were infected intraperitoneally (APHA 1998) with $0.1 \mu \mathrm{l}$ of live Y. ruckeri $\left(3 \times 10^{7} \mathrm{cfu} \cdot \mathrm{ml}^{-1}\right)$. Mortality of challenged fish was noted up to 7 days but all fish of all groups were sampled for blood indices as per the method described earlier at the end of the feeding trial (Day 3 ). Previous studies have shown that the $3^{\text {rd }}$ day showed peak levels of bacterial growth, therefore, Day 3 was chosen as sample time (Raida and Buchmann 2009).

\section{Laboratory analyses}

Blood samples were obtained from the caudal vein (vena caudalis) using syringes. Plasma was collected after centrifugation (3600 $\mathrm{g}$ for $5 \mathrm{~min}$ ) and stored in the freezer at $-70{ }^{\circ} \mathrm{C}$.

Blood was used for the testing of biochemical indices. Plasma glucose concentrations were measured colorimetrically according to Trinder (1969), total protein was measured according to the method of Lowry et al. (1952) and albumin was measured following the method of Wotton and Freeman (1982). Albumin-globulin ratio was calculated by diving albumin values by globulin value. 
The blood was digested with concentrated nitric acid (Aristar grade, BDH Ltd., UK) at $100{ }^{\circ} \mathrm{C}$, and analyzed for concentrations of total sodium $(\mathrm{Na})$, potassium $(\mathrm{K})$, chlorine $(\mathrm{Cl})$, calcium $(\mathrm{Ca})$ and magnesium $(\mathrm{Mg})$ by flame atomic absorption spectroscopy (AAS) using an instrumentation laboratory 157 atomic absorption spectrophotometer.

\section{Statistical analyses}

All data obtained from experimental groups were analyzed in Statistical Package for the Social Sciences (SPSS) 15.0 package program with Duncan's Multiple Range Test at 0.05 significance value to determine statistical differences among groups. Standard errors were also estimated.

\section{Results}

The most important components of T. vulgaris oils were phenol (40.95\%) and 2-methyl5-(1-methylethyl) $(12.12 \%)$ whereas in $F$. vulgare oils the most important components were benzene (67.99\%) and 1-methoxy-4-(1-propenyl) $(16.03 \%)$. The results of disc diffusion test showed that both oils had inhibitor activity against Y. ruckeri. It was $24.6 \pm$ $0.21 \mathrm{~mm}$ and $22.1 \pm 0.18 \mathrm{~mm}$ for $T$. vulgaris and $F$. vulgare, respectively. The MIC values of the tested T. vulgaris and F. vulgare oils were determined as $40 \mu \mathrm{g} \cdot \mathrm{ml}^{-1}$ and $60 \mu \mathrm{g} \cdot \mathrm{ml}^{-1}$, respectively.

The total protein content increased in all experimental groups compared to the control group (Table 1). The highest content of total protein was determined in group OIL2

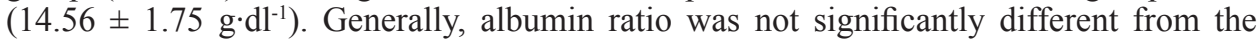
control group throughout the whole experiment $(P>0.05)$. The cholesterol concentration was significantly $(P<0.05)$ higher in group INF compared to other groups. While the triglyceride concentration showed the highest value in group INF, in group OIL1 we determined a slight decreasing trend, and group OIL2 was observed as the best treatment group in the present study for triglyceride. The glucose concentration is shown in Table 1. Compared to the CNT, the glucose value showed a gradual significant increase $(P<0.05)$. There were no significant differences in the bilirubin concentrations among treated groups and the control group $(P>0.05)$.

Table 1. Effects of herbal oil supplemented diets on biochemical properties of Oncorhynchus mykiss infected with Yersinia ruckeri

\begin{tabular}{|c|c|c|c|c|c|c|}
\hline $\begin{array}{l}\text { Experimental } \\
\text { group }\end{array}$ & $\begin{array}{l}\text { Glucose } \\
\left(\mathrm{mg} \cdot \mathrm{dl}^{-1}\right)\end{array}$ & $\begin{array}{l}\text { Total protein } \\
\quad\left(\mathrm{g} \cdot \mathrm{dl}^{-1}\right)\end{array}$ & $\begin{array}{l}\text { Albumin } \\
\left(\mathrm{mg} \cdot \mathrm{dl}^{-1}\right)\end{array}$ & $\begin{array}{l}\text { Cholesterol } \\
\left(\mathrm{mg} \cdot \mathrm{dl}^{-1}\right)\end{array}$ & $\begin{array}{l}\text { Triglyceride } \\
\left(\mathrm{mg} \cdot \mathrm{dl}^{-1}\right)\end{array}$ & $\begin{array}{l}\text { Bilirubin } \\
\left(\mathrm{mg} \cdot \mathrm{dl}^{-1}\right)\end{array}$ \\
\hline Control & $55.6 \pm 6.44^{b}$ & $6.25 \pm 2.45^{\mathrm{a}}$ & $3.46 \pm 0.40^{\mathrm{a}}$ & $261.6 \pm 32.04^{\mathrm{a}}$ & $384.0 \pm 43.17^{\mathrm{a}}$ & $0.624 \pm 0.24^{\mathrm{a}}$ \\
\hline INF & $38.4 \pm 6.19^{\mathrm{a}}$ & $12.30 \pm 3.49^{b}$ & $3.46 \pm 0.40^{\mathrm{a}}$ & $471.20 \pm 19.23^{\mathrm{b}}$ & $619.20 \pm 127.15^{\mathrm{b}}$ & $0.62 \pm 0.24^{\mathrm{a}}$ \\
\hline OIL1 & $39.00 \pm 3.32^{\mathrm{a}}$ & $12.17 \pm 1.31^{\mathrm{b}}$ & $3.42 \pm 0.23^{\mathrm{a}}$ & $324.00 \pm 35.61^{\mathrm{a}}$ & $523.40 \pm 153.05^{\mathrm{ab}}$ & $0.66 \pm 0.14^{a}$ \\
\hline OIL2 & $37.80 \pm 11.56^{\mathrm{a}}$ & $14.56 \pm 1.75^{b}$ & $4.04 \pm 0.30^{\mathrm{a}}$ & $439.20 \pm 79.50^{b}$ & $445.00 \pm 148.26^{\mathrm{ab}}$ & $0.57 \pm 0.19^{a}$ \\
\hline
\end{tabular}

Fish groups: CNT - control group, INF - fish infected with Yersinia ruckeri, OIL1 - fish infected with Yersinia ruckeri and supplemented with the mixed oils, OIL2 - fish supplemented with the mixed oils. Values are expressed as mean \pm standard error (SE). Different superscripts in the same row indicate significant $(P<0.05)$ differences between weeks by the Turkey's test.

Concentration of Na was higher in group OIL1 $\left(168.00 \pm 5.57 \mathrm{mmol}^{-1} \mathrm{l}^{-1}, P>0.05\right)$ compared to OIL2. The highest value of $\mathrm{K}$ was in the OIL1 $\left(34.93 \pm 2.2 \mathrm{mmol} \mathrm{l}^{-1}\right.$, $P<0.05)$ and the lowest value in $\mathrm{Ca}$ was recorded in the control. The best effect in $\mathrm{K}$ concentrations was shown in group OIL1. Mg concentration in fish of group OIL2 was higher than in OIL1 $(P<0.05)$ when compared to control. Plasma Cl concentration in fish of group OIL2 was higher than that in group OIL1. The lowest significant value of $\mathrm{Cl}$ was recorded in fish of group INF $(P<0.05)$, whereas the highest value was found in the control (Table 2). 
Table 2. Effects of herbal oils supplemented in diets on element status of Oncorhynchus mykiss infected with Yersinia ruckeri

\begin{tabular}{lccccc}
\hline $\begin{array}{l}\text { Experimental } \\
\text { group }\end{array}$ & $\begin{array}{c}\mathrm{K} \\
\left(\mathrm{mmol} \cdot \mathrm{l}^{-1}\right)\end{array}$ & $\begin{array}{c}\mathrm{Cl} \\
\left(\mathrm{mmol} \cdot \mathrm{l}^{-1}\right)\end{array}$ & $\begin{array}{c}\mathrm{Ca} \\
\left(\mathrm{mg} \cdot \mathrm{dl}^{-1}\right)\end{array}$ & $\begin{array}{c}\mathrm{Na} \\
\left(\mathrm{mmol} \cdot l^{-1}\right)\end{array}$ & $\begin{array}{c}\mathrm{Mg} \\
\left(\mathrm{mg}^{-1} \mathrm{dl}^{-1}\right)\end{array}$ \\
\hline Control & $15.34 \pm 4.93^{\mathrm{a}}$ & $134.80 \pm 6.81^{\mathrm{b}}$ & $3.9 \pm 0.12^{\mathrm{a}}$ & $159.8 \pm 5.72^{\mathrm{a}}$ & $4.79 \pm 1.06^{\mathrm{a}}$ \\
INF & $31.13 \pm 6.25^{\mathrm{b}}$ & $97.80 \pm 20.58^{\mathrm{a}}$ & $7.15 \pm 1.98^{\mathrm{b}}$ & $154.20 \pm 5.85^{\mathrm{a}}$ & $11.74 \pm 3.61^{\mathrm{b}}$ \\
OIL1 & $34.93 \pm 2.21^{\mathrm{b}}$ & $112.00 \pm 3.08^{\mathrm{a}}$ & $8.38 \pm 1.19^{\mathrm{c}}$ & $168.00 \pm 5.57^{\mathrm{a}}$ & $10.73 \pm 1.62^{\mathrm{b}}$ \\
OIL2 & $32.15 \pm 6.41^{\mathrm{b}}$ & $105.20 \pm 16.53^{\mathrm{a}}$ & $7.49 \pm 0.85^{\mathrm{ab}}$ & $157.20 \pm 13.05^{\mathrm{a}}$ & $13.16 \pm 1.74^{\mathrm{b}}$ \\
\hline
\end{tabular}

Fish groups: CNT - control group, INF - fish infected with Yersinia ruckeri, OIL1 - fish infected with Yersinia ruckeri and supplemented with the mixed oils, OIL2 - fish supplemented with the mixed oils. Values are expressed as mean \pm standard error $(\mathrm{SE})$. Different superscripts in the same row indicate significant $(P<0.05)$ differences between weeks by Tukey's test.

\section{Discussion}

Aquaculture fish production increased significantly over the past few decades. However, stressful environment also leads to consequent suppression of the immune system, increasing the susceptibility of fish to infectious diseases; infections routinely occur in aquaculture and lead to substantial economic losses. Massive use of antimicrobials and vaccination for disease control has suppressed the growth in aquatic animals due to spread of antimicrobial-resistant bacteria and the presence of antimicrobial residues in aquaculture products and the environment. One of the most promising methods of controlling diseases in aquaculture is by strengthening the defense mechanism of fish through prophylactic administration of natural plant products (Agarwal and Singh 1999; Devasagayam and Sainis 2002) which is considered as a promising alternative to chemotherapy and vaccines (Secombes 1994).

The present study demonstrated that diet supplementation with $T$. vulgaris and $F$. vulgare oils showed increases in all biochemical variables. Our results are in agreement with the report of Sahu et al. (2007) who reported that serum protein, albumin and bilirubin concentrations in Labeo rohita fingerlings fed Magnifera indica kernel were higher than in control. Similar results were reported by Rao et al. (2006). Different values in biochemical variables are likely to be a result of the enhancement of the non-specific immune response of fish. The plant oils used in this study could decrease glucose values in treatment groups compared to control. Our results for this variable showed similarity with the results of Sahu et al. (2007) and Citarasu et al. (2006). They found reduced glucose concentrations in the aquatic animals fed with herbal immunostimulant diets. Furthermore, Ji et al. (2007) reported low blood glucose concentrations and plasma glutamic oxaloacetic transaminase in juvenile Japanese flounder fed with herbal mixtures. The decrease of glucose concentrations might be due to the capability of plant oils to reduce the effects of stressors.

In our study, we also determined electrolyte content $(\mathrm{Na}, \mathrm{K}, \mathrm{Mg}, \mathrm{Cl}, \mathrm{Ca})$ in fish serum. Among all experimental groups only plasma $\mathrm{Na}$ values were not significant. All other plasma electrolytes revealed significant differences, especially $\mathrm{K}$ and $\mathrm{Mg}$. Chlorine contents in plasma were observed to decrease gradually. Our results are in agreement with the findings of Sivaram et al. (2004) in juvenile greasy groupers (Epinphelus tauvina) with Ocimum sanctum and Withania somnifera, and E. tauvina juveniles with herbal plant mixture diets.

This study showed that mixed using of $T$. vulgaris and $F$. vulgare oils in diet had the potential effect on enhancing biochemical properties and trace elements in O. mykiss infected with $Y$. ruckeri. 


\section{Acknowledgements}

This research was supported by the Unit of Scientific Projects of Tunceli University (TUNIBAP), Turkey.

\section{References}

Agarwal SS, Singh VK 1999: Immunomodulators studies on Indian medicinal plants and synthetic peptides. Part 1: medicinal plants. Proc Indian Natl Sci Acad 65: 179-204

Akgul A 1993: Spice science and technology. Food Science Association, Ankara, 451 p.

APHA 1998: Standard methods for the examination of water and waste water. 20th Edition. American Public Health Association, Washington DC

Bagamboula CF, Uyttendaele M, Debevere J 2004: Inhibitory effect of thyme and basil essential oils, carvacrol, thymol, estragol, linalool and p-cymene towards Shigella sonnei and S. flexneri. Food Microbiol 21: 33-42

Bauer AW, Kirby WM, Sherris JC, Turek M 1996: Antibiotic susceptibility testing by standardized single disc method. Am J Clin Pathol 44: 493-496

Baytop T 1984: Treatment with plants in Turkey. Istanbul University Press, Istanbul, Turkey, $167 \mathrm{p}$.

Citarasu T 2010: Herbal biomedicines: a new opportunity for aquaculture industry. Aqua Int 18: 403-414

Citarasu T, Sivaram V, Immanuel G, Rout N, Murugan V 2006: Influence of selected Indian immunostimulant herbs against white spot syndrome virus (WSSV) infection in black tiger shrimp, Penaeus monodon with reference to haematological, biochemical and immunological changes. Fish Shellfish Immunol 21: 372-384

Coppo JA 2001: Internal environment comparative physiology. Ed Dunken, Buenos Aires, Argentina, 297 pp.

Dada AA, Ikuerowo M 2009: Effects of ethanolic extracts of garcinia kola seeds on growth and haematology of catfish (Clarias gariepinus) broodstock. African J Agri Res 4: 344-347

Davis PH 1982: Flora of Turkey and the East Aegean Island. University Press, Edinburg, 97 p.

Devasagayam TPA, Sainis KB 2002: Immune system and antioxidants, especially those derived from Indian medicinal plants. Indian J Exp Biol 40: 639-655

Essawi T, Srour M 2000: Screening of some Palestinian medicinal plants for antibacterial activity. J Ethnopharmacol 70: 343-349

Harikrishnan R, Balasundaram C, Heo MS 2010: Potential use of probiotics and triherbal enriched diet to control Aeromonas hydrophila infection in carp. Dis Aquat Org 92: 41-49

Ji SC, Jeong GS, Im GS, Lee SW, Yoo JH, Taki K 2007: Dietary medicinal herbs improve growth performance, fatty acid utilization and stress recovery of Japanese flounder. Fish Sci 73: 70-76

Karaman S, Digrak M, Ravid U, Ilcim A 2001: Antibacterial and antifungal activity of the essential oils of Thymus revolutus Celak from Turkey. J Ethnophar 76: 183-186

Kirubakaran CJW, Alexander CP, Dinakaran Michael R 2010: Enhancement of non-specific immune responses and disease resistance on oral administration of Nyctanthes arbortristis seed extract in Oreochromis mossambicus (Peters). Aquacul Res 41: 1630-163

MacMillan JR 2001: Aquaculture and antibiotic resistance: a negligible public health risk? World Aqua 32: 49-68

Ozcan MM, Sagdic L, Ozkan O 2006: Inhibitory effects of spice essential oils on the growth of Bacillus species. J Med Food 9: 418-421

Raida MK, Buchmann K 2009: Innate immune response in rainbow trout (Oncorhynchus mykiss) against primary and secondary infections with Yersinia ruckeri O1. Dev Comp Immunol 33: 35-45

Rao YV, Das BK, Jyotrymayee P, Chakrabarti R 2006: Effect of Achyranthes aspera on the immunity and survival of Labeo rohita. Fish Shellfish Immunol 20: 263-273

Rasooli I., Mirmostafa SA 2003: Bacterial susceptibility to and chemical composition of essential oils from Thymus kotschyanus and Thymus persicus. J Agric Foof Chem 51: 2200-2205

Reed LJ, Muench H 1938: A simple method of estimating fifty per cent endpoints. Am J Hyg 27: 493-497

Secombes CJ 1994: Enhancement of fish phagocyte activity. Fish Shellfish Immunol 4: 421-436

Shahat AA, Ibrahim AY, Hendawy SF, Omer EA, Hammouda FM, Abdel- Rahman FH, Saleh MA 2011: Chemical composition, antimicrobial and antioxidant activities of essential oils from organically cultivated fennel cultivars. Molecules 16: 1366-1377

Sahu S, Das BK, Pradhan J, Mohapatra BC, Mishra BK, Sarangi NN 2007: Effect of Magnifera indica kernel as a feed addiitive on immunity and resistance to Aeromonas hydrophila in Labeo rohita fingerlings. Fish Shellfish Immunol 23: 109-118

Sivaram V, Babu MM, Immanuel G, Murugadass S, Citarasu T, Marian MP 2004: Growth and immune response of juvenile greasy groupers (Epinephelus tauvina) fed with herbal antibacterial active principle supplemented diets against Vibrio harveyi infections. Aquaculture 237: 9-20

Smith P, Hiney MP, Samuelsen OB 1994: Bacterial resistance to antimicrobial agents used in fish farming: a critical evaluation of method and meaning. Ann Rev Fish Dis 4: 273-313

Sugiura SH, Dong FM, Hardy RW 1998: Effects of dietary supplements on the availability of minerals in fish meal; preliminary observations. Aquaculture 160: 283-303 
Trinder P 1969: Estimation of triglyceride in blood GPO-PAP enzymatic method. American Clin Biochem 6: 24-27

Wotton ID, Freeman H 1982: Microanalysis in medicinal biochemical. Churchill Livingstone, Edinburgh, London, 1974 p. 